\title{
QUEEN'S
UNIVERSITY
BELFAST
}

\section{Religious actions speak louder than words: exposure to credibility enhancing displays predicts theism}

Lanman, J. A., \& Buhrmester, M. D. (2017). Religious actions speak louder than words: exposure to credibility enhancing displays predicts theism. Religion, Brain, and Behavior, 7(1), 3-16.

https://doi.org/10.1080/2153599X.2015.1117011

\section{Published in:}

Religion, Brain, and Behavior

Document Version:

Peer reviewed version

Queen's University Belfast - Research Portal:

Link to publication record in Queen's University Belfast Research Portal

Publisher rights

(c) 2015 Taylor \& Francis

The Version of Record of this manuscript has been published

and is available in Religion, Brain and Behavior http://www.tandfonline.com/doi/full/10.1080/2153599X.2015.1117011

\section{General rights}

Copyright for the publications made accessible via the Queen's University Belfast Research Portal is retained by the author(s) and / or other copyright owners and it is a condition of accessing these publications that users recognise and abide by the legal requirements associated with these rights.

Take down policy

The Research Portal is Queen's institutional repository that provides access to Queen's research output. Every effort has been made to ensure that content in the Research Portal does not infringe any person's rights, or applicable UK laws. If you discover content in the Research Portal that you believe breaches copyright or violates any law, please contact openaccess@qub.ac.uk. 
Religious Actions Speak Louder than Words:

Exposure to Credibility Enhancing Displays Predicts Theism

\author{
Jonathan A. Lanman ${ }^{1}$ \\ Michael D. Buhrmester ${ }^{1,2}$ \\ ${ }^{1}$ Institute of Cognition and Culture, Queen's University, Belfast, 2-4 Fitzwilliam St, Belfast \\ BT7 1NN, UK \\ ${ }^{2}$ Institute of Cognitive and Evolutionary Anthropology, University of Oxford, 64 Banbury \\ Road, Oxford OX2 6PN, UK
}

\title{
CORRESPONDING AUTHOR:
}

Dr. Jonathan A. Lanman, Institute of Cognition and Culture, Queen's University, Belfast, 2-4 Fitzwilliam St, Belfast BT7 1NN, UK, j.lanman@qub.ac.uk, phone: +44 (0) 2890971173

\section{ACKNOWLEDGEMENTS:}

The work of both authors on this paper was supported by a Large Grant from the UK's Economic and Social Research Council (REF RES-060-25-0085) entitled "Ritual, Community, and Conflict" and an award from the John Templeton Foundation entitled "Religion's Impact on Human Life" (\#37624). Ideas expressed in this publication are those of the authors and do not necessarily reflect the views of these granting agencies. The authors would like to thank Richard Sosis, Aiyana Willard, and 3 anonymous reviewers for their helpful comments on the 
manuscript. The authors declare no potential conflicts of interests with respect to the authorship and/or publication of this article.

\begin{abstract}
:
One of the central aims of the cognitive science of religion (CSR) is to explain why supernatural agent beliefs are so widespread. A related but distinct aim is to explain why some individuals hold supernatural agent beliefs but others do not. Here, we aim to provide an initial test of the power of exposure to what Henrich calls "credibility enhancing displays" (or "CREDs") in determining whether or not an individual holds explicit supernatural agent beliefs. We present evidence from two studies of Americans suggesting that exposure to CREDs, as measured by a scale we developed and validated, predicts current theism vs. non-theism, certainty of God's existence/non-existence, and religiosity while controlling for overall religious socialization. These results are among the first to empirically support the theorized significance of CREDs for the acquisition of supernatural agent beliefs.
\end{abstract}

Keywords: cognitive science of religion, credibility enhancing displays, CREDs, religious socialization, religious emphasis, theism, atheism, non-theism 


\section{Religious Actions Speak Louder than Words: Exposure to Credibility Enhancing Displays Predicts Theism}

\section{Introduction}

One of the central aims of the cognitive and evolutionary study of religion is to explain the widespread presence of supernatural agent beliefs across cultures and history. Cognitive and evolutionary scholars of religion have offered a variety of explanations for this ubiquity. Some (e.g. Atran, 2002; Barrett, 2004; Boyer, 2001; Pyysiäinen, 2009) argue that a variety of panhuman cognitive biases and tendencies work to make supernatural agent beliefs both memorable and believable, consequently leading to their cultural success. Others (e.g. Bering, 2006; 2010; Johnson, 2005) argue that an implicit belief in some form of supernatural agency is an evolved feature of human psychology that works to prevent reputation-damaging behavior. Still others (e.g. Irons, 2001; Purzycki \& Sosis, 2009; Sosis \& Bulbulia, 2011; Sosis \& Kiper, 2014) argue that supernatural agent beliefs are components of adaptive religious systems that evolve to help human communities overcome the problem of cooperation.

None of the mechanisms hypothesized as explaining the ubiquity of such beliefs, however, deterministically produce explicit supernatural agent beliefs in all minds (Geertz \& Markússon, 2010; Norris \& Inglehart, 2004; Zuckerman, 2007), raising the question of why some individuals possess supernatural agent beliefs but others do not. This question has attracted less attention, but interest is growing (Gervais \& Najle, in press; Lanman, 2013; Norenzayan \& Gervais, 2013). Gervais and Norenzayan (2012), for instance, find that individual differences in analytical thinking predict religious disbelief. Further, Norenzayan, Gervais, and 
Trzesniewski (2012), find mentalizing ability as significant in predicting high vs. low religious belief. Similarly, Willard and Norenzayan (2013), find mentalizing ability a significant predictor of belief in God through the mediating factors of mind-body dualism (Bloom, 2004) and teleological reasoning (Kelemen, 2004).

Willard and Norenzayan note, however, that social learning also likely influences levels of supernatural agent belief, and find among an adult sample of Americans that the percentage of church attenders in an individual's county significantly predicts their levels of belief in God. And indeed, socialization is one of the most well-founded explanations of why some individuals come to believe in supernatural agents and others do not (Beit-Hallahmi, 2015; Gervais \& Najle, in press). Work in both the psychology and sociology of religion suggests that socialization, most notably by parents, has a significant impact not only on which supernatural agents children grow up to believe in, but whether they believe in such agents at all (Albrecht, Cornwall, \& Cunningham, 1988; Baker \& Smith, 2009; Dudley, 1978; 1999; Flor \& Knapp, 2001; Hood, Hill, \& Spilka, 2009; Hunsberger, 1980; 1983; Hunsberger \& Altemeyer, 2006; Hunsberger \& Brown, 1984; Ozorak, 1989; Sherkat, 1991; Wilson \& Sherkat, 1994). This social learning account of religious affiliation and theism follows a long tradition in social psychology stressing the role of models in the transmission of representations and behaviours (Bandura, 1971; 1986; Hovland \& Weiss, 1951).

Social learning and cognitive biases need not be seen as conflicting explanations for at least two reasons. First, it is possible that both factors independently explain variance in supernatural agent beliefs. Second, some relevant cognitive biases may have evolved precisely to allow human beings to better benefit from social learning (Henrich \& McElreath, 2003; 
Richerson \& Boyd, 2005). Examples of proposed biases in social learning include a prestige bias, which biases learners towards accepting information from individuals with high levels of social prestige (Henrich \& Gil-White, 2001), and a conformist bias, which biases learners towards accepting the most common beliefs, attitudes, and practices within their ingroups (Henrich \& Boyd, 1998).

\section{Credibility Enhancing Displays (CREDs)}

In 2009, Henrich made a prima facie case for the existence of an additional social learning bias with significant implications for explaining why some individuals come to believe in the existence of supernatural agents and others do not. This bias is to accept information, such as information about the existence of supernatural agents, expressed verbally by cultural models to the extent that these verbalizations are accompanied by "credibility enhancing displays" or "CREDs" (2009). These are, according to Henrich, "displays by a model that would seem costly to the model if he or she held beliefs different from those he or she expresses verbally" (2009, p.244). CREDs need not have an actual net fitness cost to affect cultural learning (e.g. eating blue mushrooms after verbally claiming their lack of toxicity is a CRED for the claim but is not costly) and concern the transmission of beliefs rather than the signaling of commitment to a group, distinguishing CREDs from costly signals. To say we have a CREDs bias, then, is to say that we have a bias to believe particular pronouncements from cultural models to the extent that they "walk the walk" and not just "talk the talk" in relation to those pronouncements.

Henrich offers both an evolutionary rationale for the development of this bias and evidence from a variety of sub-fields of psychology of its existence. Henrich argues that a new type of deception emerged with the evolution of language, such that manipulative individuals 
could express an idea cheaply through speech that, if believed by learners, would benefit the manipulator at a cost to the learners. In this novel environment, a selection pressure would exist for any cognitive mechanism that would help cultural learners reject deceptive and manipulative information. Henrich proposes that natural selection responded by "constructing a kind of cultural immune system [...] designed to assess a potential model's degree of belief or commitment to a symbolically communicated belief using the models' displays or actions" (2009, p. 247). Henrich's claim fits well with the long-standing literature in social and developmental psychology, which shows behavioral modelling to be more effective in transmitting attitudes and behaviors than verbal modelling (Eagley, Wood, \& Chaiken, 1978; Fisher, Fisher, Bryan, \& Misovich, 2002; Harper \& Sanders, 1975; Harris \& Koenig, 2006; Harris, Pasquini, Duke, Asscher, \& Pons, 2006; Walster, Aronson, \& Abrahams, 1966). To date, however, little empirical work has directly examined the effects of exposure to CREDs on religious transmission (Lanman, 2012).

Henrich argues that the existence of a CREDs bias allows for the cultural evolution of stable sets of costly practices and the linking of these practices to group-beneficial ideologies, and models by both Henrich (2009) and by Wildman \& Sosis (2011) support this claim. Our argument, however, concerns an additional implication of a CREDs bias. More specifically, a CREDs bias may have significant implications for explaining why some individuals come to believe in the existence of supernatural agents and others do not. In fact, the CREDs bias may be particularly relevant for supernatural agent beliefs, which are not easily confirmed or disconfirmed by direct experience or intuition and are especially reliant on testimony, and potentially CREDs, for their cultural success. 
A key implication of the CREDs bias for supernatural agent beliefs is that not all religious socialization is created equal. Religious socialization involves both verbalizations (e.g. telling learners that supernatural agents exist, describing their interests and behaviors, instructing learners of how they should interact with such agents, etc.) as well as actions that we may label as CREDs (e.g. following moral, dietary, and sartorial norms established and/or endorsed by said supernatural agents; attempting communication with said agents, and attending collective gatherings devoted to said agents). Our analysis of CREDs suggests that religious socializers will be especially effective at transmitting beliefs in supernatural agents if they perform CREDs for their stated beliefs. Conversely, verbal assertions of the existence and importance of supernatural agents without appropriate CREDs should be less effective.

A consistent but quite limited body of evidence concerning religious commitment and belief in the Western monotheistic God supports our hypotheses. For example, Roger Dudley's longitudinal study of $7^{\text {th }}$ Day Adventists found that a key predictor of whether an individual remained in the $7^{\text {th }}$ Day Adventist Church as an adult was exposure to parental church attendance and the frequency of their worshipping together as a family (1978; 1999). Similarly, Bader \& Desmond (2006) found that parents exhibiting greater consistency between the importance they attached to religion and their actual church attendance were more successful in producing higher levels of religiosity in their children. And more recently, Bengston, Putney, \& Harris (2013) analysed a large $(N>3500)$ qualitative sample of Americans and repeatedly stressed the role of perceived religious hypocrisy in apostasy.

In relation to theism and non-theism specifically, Hunsberger \& Altemeyer (2006) found significant differences between samples of theists and atheists on a measure of the "religious 
emphasis" shown by parents and other important figures. Similarly, in an international but nonrandom sample Lanman (2012) found that theists reported more religious CREDs exposure during their upbringing than non-theists.

Overall, the empirical literature supporting the role of CREDs in the transmission of theism is suggestive but far from conclusive. First, the dependent measures in question have more often been religious affiliation with the specific religious traditions of one's parents than theistic belief. Second, past studies have not clearly separated the effects of verbalizations and CREDs. For instance, many of the items in Hunsberger \& Altemeyer's religious emphasis scale cover both verbalizations and CREDs (e.g., to what extent did the important people in your life emphasize: "making religion the center, the most important part of your life," [p.43]), Similarly, Bader \& Desmond (2006) sometimes interpret the 'importance' parents attach to religion as indicating verbalizations (verbally emphasizing how important religion is) and sometimes as likely CRED-related ("permeating life within the household" [p.319]). And while Lanman (2012) did focus on theism and non-theism specifically and did isolate CREDs from general religious socialization, he did not produce a validated CREDs exposure measure and only documented a significant difference between theists and non-theists, rather than establishing the predictive power of CREDs on theism.

A remaining question from this literature is the extent to which being exposed to religious CREDs predicts whether or not an individual becomes a theist or non-theist. Is it really "walking the walk" that facilitates the transmission of theism, as the CREDs hypothesis predicts, or is CREDs exposure simply another way of speaking about the long-studied general process of religious socialization? 


\section{The Present Studies}

To better ascertain the importance of exposure to religious CREDs for explaining theism and non-theism, we set out to 1) develop and validate a CREDs Exposure Scale and 2) test its predictive power for theistic belief and religious identity while controlling for the effects of overall religious socialization.

\section{Study 1}

In our first study, we surveyed a sample of Americans to test two hypotheses. First, we predicted that CREDs exposure is a distinct construct, irreducible to more general constructs of religious socialization and demographics (Hypothesis 1). Second, we predicted that CREDs exposure is an important predictor of both dichotomous (theism vs. non-theism) and continuous (belief certainty) measures of theistic belief, even while controlling for effects of overall religious socialization (Hypothesis 2).

\section{Methods}

Sample. Two hundred and sixteen Americans (63\% Females; mean age $=37.3$ years; $S D$ $=13.7$; age range from 18 to 75 years; $82 \%$ Caucasian) participated online via Amazon's Mechanical Turk (for evaluations of Mechanical Turk's suitability for social science research, see Buhrmester, Kwang, \& Gosling, 2011; Horton, Rand, \& Zeckhauser, 2011; Mason \& Suri, 2012; Paolacci, Chandler, \& Ipeirotis, 2010) in return for a small amount of monetary compensation $^{\text {i. }}$ Participants' current religious affiliation was as follows: $46 \%$ non-religious, $29 \%$ Protestant denominations, 17\% Catholic, 2\% Jewish, .5\% Muslim, 2\% Buddhist, 3.5\% other/unspecified ${ }^{\mathrm{ii}}$. Participants read that the survey concerned their 'thoughts and experiences 
regarding religion,' provided informed consent, then completed the following battery of scales in the order presented.

\section{Measures.}

CREDs Exposure. We initially generated ten items based on Henrich (2009) and exploratory survey work conducted by Lanman (2012). On seven point Likert scales (i.e., 'to no extent at all' ... 'to an extreme extent'), participants rated the extent to which they observed their caregivers engage in behavioral modeling of religion during their upbringings (e.g., 'To what extent did your caregiver(s) attend religious services or meetings?'; see Appendix for the scale) $)^{\mathrm{iii}}$.

Religious Emphasis. As a measure of overall religious socialization, we used Hunsberger \& Altemeyer's (2006) twenty-item measure of religious emphasis. On seven point Likert scales, participants rated the extent to which important people in their lives emphasized various religious actions and beliefs during their upbringing (e.g., To what extent did they tell you to "make religion the center, the most important part of your life?" and "discuss moral do's and don'ts in religious terms?”; $\alpha=.98)$.

Outcome measures. To assess belief in God, participants answered yes or no to the question 'Do you currently believe that God exists?' (66\% of participants responded 'yes'). To assess certainty of God belief, on a seven-point Likert scale ( 1 = extremely certain God does not exist, 7 = extremely certain God exists) participants answered the question 'How certain are you about the existence of God?' $(M=4.56, S D=2.29)$. Finally, all participants completed a set of demographic questions (age, gender, ethnicity, household income, religious affiliation, caregiver status during upbringing) and were debriefed.

\section{Results}


Preliminary analyses. To examine the internal structure of the ten initial CREDs items and explore dimension reduction, we conducted a principle component analysis (Jolliffe, 2002). Two components emerged, with component one accounting for $54.9 \%$ of the variance (eigenvalue $=5.49)$, and the second component accounting for $13.8 \%$ (eigenvalue $=1.38)$. Inspection of the scree plot also indicated two components. The three items that made up the second component concerned highly specific types of displays (i.e., sticking to religiouslyprescribed food choices, clothing styles, and fasting rituals). In addition, means to these three items were relatively lower (less than $M=2.1$ ) compared to the other seven items (range $M=2.5$ to 3.9). Given our goal to produce a short scale that could apply across a range of religious traditions, which vary considerably in their dietary and sartorial norms, we decided these items did not fit the scale's intent and removed them from the scale. The remaining seven items had high internal consistency, $\alpha=.92$, with scale $M=3.27$ and $S D=1.51$. Corrected item-total correlations ranged from .71 to .81 . See Table 1 for a summary of scale characteristics and Table 2 for inter-item correlations and item means and standard deviations.

With our seven-item CREDs exposure scale in hand, we examined its relationship with Hunsberger \& Altemeyer's (2006) religious emphasis scale (see Table 3 for a summary). As expected, CREDs was moderately correlated with religious emphasis, $r(214)=.56, p<.001$. To explore the factor structure of the CREDs scale in relation to the religious emphasis scale, we conducted an exploratory factor analysis (maximum likelihood extraction with direct oblimin rotation). Two factors emerged, with one factor (all 20 emphasis items) accounting for 58.04\% of the variance (eigenvalue $=15.67$ ) and a second factor (all seven CREDs items) accounting for $11.35 \%$ of the variance (eigenvalue $=3.07$ ). Factors were moderately correlated, $r=.51$. 
Inspection of the scree plot also indicated two factors. Together, these results suggest that our CREDs exposure scale and the religious emphasis scale represent related but distinct constructs.

We also explored CREDs' relationship with demographic variables (i.e., age, gender, ethnicity, and household income) and caregiver type during upbringing (i.e., single parent/guardian, two cohabiting parents/guardians, two divorced/separated parents/guardians, more than two parents/guardians, other). The CREDs scale was not associated with any of these variables, $|r|$ 's $<.05, F^{\prime} s<1.5, p$ 's $>.20$. In addition, demographic variables were largely unrelated to the outcome measures (i.e., belief in God, certainty of belief in God), $|r|$ 's $<.14, F$ 's $<1.9, p$ 's $>.12$, except for age which was weakly associated with belief in God, $r(213)=.21, p$ $<.01$, and certainty of belief in God, $r(213)=.20, p<.01$. In addition, ethnicity was related to belief in God, Pearson $\chi^{2}(4)=15.23, p<.01$, and certainty of belief in God, $F(4,209)=4.18, p$ $<.01$, indicating that African-American participants were especially likely to believe that God exists and report high certainty. In preliminary regression analyses that controlled for age and ethnicity in the models presented below, age and ethnicity did not significantly change the pattern of effects; consequently they were dropped from models reported here.

Regression analyses. To test the hypothesis that CREDs exposure predicts belief in God (dichotomous) beyond the effect of religious emphasis, we conducted two logistic regressions. In the first, religious emphasis was entered as a predictor of belief in God. Emphasis predicted belief in God, unstandardized $b=.22, S E$ of $b=.09$, Wald $^{2}(1)=6.58, p=.01$, OR $=1.25,95 \%$ CI of OR: 1.05, 1.48. In the second, CREDs was added as a second predictor in the same model. Consistent with our hypothesis, CREDs predicted belief in God, unstandardized $b=.52, S E$ of $b$ $=.13$, Wald $\chi^{2}(1)=14.94, p<.001, O R=1.68,95 \%$ CI of OR: $1.29,2.18$, whereas religious 
emphasis did not, $b=-.01, S E$ of $b=.11$, Wald $\chi^{2}(1)=.01, n . s$. (see Table 4 for a summary). The predicted probability for persons with low CREDs exposure (-1SD) to report believing in God was $50 \%$. In contrast, the predicted probability for persons with high CREDs exposure (+1SD) to report believing in God was $82 \%$.

Next, using linear regressions we followed the same two-step procedure with regard to the certainty of God belief outcome. In the first regression, emphasis predicted belief certainty, $b$ $=.21, S E$ of $b=.09,95 \% \mathrm{CI}$ of $b: .04, .39, t(214)=2.44, p=.02$. Adding CREDs as a predictor to the model, CREDs predicted belief certainty, $b=.39, S E$ of $b=.12,95 \%$ CI of $b: .15, .63, t$ $(213)=3.24, p=.001$, whereas emphasis did not, $b=.03, S E$ of $b=.10,95 \%$ CI of $b:-.18, .23, t$ $(213)=.27$, n.s.

Participants indicated their caregivers' religious affiliation during their upbringing which we coded dichotomously ( $90 \%$ had religious caregivers; $10 \%$ had non-religious caregivers). To test whether the pattern of effects reported above were similar amongst participants raised with religious caregivers, we excluded participants with non-religious caregivers from the dataset and re-ran the analyses above. The results were very similar. CREDs predicted belief in God, $b=.54$, SE of $b=.14$, Wald $\chi^{2}(1)=13.71, p<.001, \mathrm{OR}=1.71,95 \% \mathrm{CI}$ of OR: $1.29,2.27$, whereas religious emphasis did not, $b=-.05$, SE of $b=.11$, Wald $\chi 2(1)=.17, n . s$. CREDs also predicted certainty of belief in God, $b=.37$, SE of $b=.13,95 \%$ CI of $b: .12, .62, t(191)=2.90, p<.01$, whereas emphasis did not, $b=-.02$, SE of $b=.11,95 \% \mathrm{CI}$ of $b:-.23, .19, t(191)=-.20, n . s$. These results suggest that the effects of CREDs do not merely reflect a tendency for nonreligious caregivers to raise non-religious children and religious caregivers to raise religious 
children. Rather, they suggest that the behavioral modeling of religious caregivers has a significant impact on whether or not they successfully transmit theistic beliefs to their children.

\section{Discussion}

The results of Study 1 supported both of our hypotheses. In support of Hypothesis 1, our seven-item CREDs exposure measure demonstrated high internal consistency and discriminant validity. In support of Hypothesis 2, CREDs exposure predicted both dichotomous and continuous measures of theistic belief. While religious emphasis was associated with God belief and belief certainty on its own, our results suggest that this is due to shared variance with our CREDs exposure scale. When including the CREDs exposure scale in each model, CREDs was strongly predictive of both outcomes whereas religious emphasis was not. Controlling for religious emphasis, participants who reported relatively high levels of CREDs exposure were especially likely to report believing in God and feeling especially certain in their theistic belief. Conversely, participants who reported relatively low levels of CREDs exposure were especially likely to report not believing in God and feeling especially certain in their atheistic belief. Encouraged by these findings, we sought to replicate them in a new sample as well as rule out an alternative hypothesis.

\section{Study 2}

In Study 2, we aimed to replicate the results from Study 1 with a new sample using only the final seven-item CREDs exposure scale and to test two additional hypotheses derived from lingering questions. First, would CREDs exposure also predict religiosity? There is a relevant distinction between theism and religiosity, as many theists do not see themselves as belonging to a particular religious tradition. Nevertheless, theistic CREDs, we argue, do not merely attest to 
theism but to the theistic cultural traditions professed by models (Cohen, 2009; Johnson, Hill, \& Cohen, 2011). Consequently, as Hypothesis 3, we predicted that our CREDs exposure measure would predict both dichotomous and continuous measures of religious identity.

Second, might the effects of CREDs exposure be explained by a third variable - namely one's own religious practice during one's upbringing? It could be argued that one's responses on the CREDs exposure measure merely reflect one's own religious actions during one's upbringing. In line with a cognitive dissonance account (Festinger, 1957), reflecting on one's own religious practices may serve to solidify one's religious belief irrespective of CREDs exposure. We would argue that, should such an effect exist, it is not responsible for the effect of CREDs on theism and religiosity. Thus, we predicted that the influence of CREDs exposure on belief and religiosity measures would hold while controlling not only for religious emphasis but also for one's own previous religious practice (Hypothesis 4).

\section{Methods}

Sample. One hundred Americans participated online via Mechanical Turk (56\% females; mean age $=36.1$ years; $S D=13.1$; age range from 18 to 73 years; $80 \%$ Caucasian; $44 \%$ nonreligious, 36\% Protestant denominations, $16 \%$ Catholic, 2\% Jewish, 1\% Hindu, $1 \%$ Sikh). General participation procedure was the same as Study 1.

Measures. Participants first completed the seven-item CREDs exposure scale followed by the religious emphasis scale. As in Study 1, participants then completed two questions to assess their current belief in the existence of God ( $68 \%$ believed in God) and the certainty of God belief $(M=4.59, S D=2.3)$. In addition, participants were asked whether or not they currently followed a religion ( $56 \%$ responded 'yes'), the extent to which they themselves 
practiced religion during their upbringing $(M=3.76, S D=1.74)$, and Shariff, Cohen, and Norenzayan's (2008) six self-reported religiosity items on five-point Likert scales (e.g., 'My religion or faith is an important part of my identity'; $\alpha=.94, M=2.88, S D=1.27)$. Last, participants completed demographic questions (age, gender, ethnicity, religious affiliation, caregiver status during upbringing) and were debriefed.

\section{Results}

Preliminary Analyses. As in Study 1, CREDs exposure was not associated with demographic variables (i.e., age, gender, ethnicity, household income, and caregiver type during upbringing), $r$ 's $<.10, F^{\prime} s<.95, p$ 's $>.28$. In addition, demographic variables were not related to primary outcome measures (i.e., belief in God, certainty of belief in God, religiosity), $|r|$ 's < $.14, F^{\prime} \mathrm{s}<1.9, p$ 's $>.12$. Lastly, we conducted a factor analysis of the religious emphasis and CREDs items parallel to Study 1. The results replicated those in Study 1, with the religious emphasis items loading on one factor $(60.04 \%$ of the variance; eigenvalue $=16.21)$ and the CREDs items on a separate second factor $(11.32 \%$ of the variance; eigenvalue $=6.06)$.

Regression Analyses. We then conducted regression analyses parallel to those in Study 1. As seen in Table 4, the results were consistent with Study 1. In a first logistic regression, religious emphasis predicted God belief, $b=.36, S E$ of $b=.14$, Wald $\chi^{2}(1)=6.36, p=.01, O R=$ 1.43, $95 \%$ CI of OR: $1.08,1.89$. After adding CREDs as a predictor to the model, CREDs predicted God belief, $b=.72, S E$ of $b=.21$, Wald $\chi^{2}(1)=11.36, p=.001$, OR $=2.05,95 \% \mathrm{CI}$ of OR: $1.35,3.11$, whereas emphasis did not, $b=-.02, S E$ of $b=.18$, Wald $\chi^{2}(1)=.01$, n.s. The predicted probability for persons with low CREDs exposure (-1SD) to report believing in God 
was $46 \%$. In contrast, the predicted probability for persons with high CREDs exposure (+1SD) to report believing in God was $88 \%$.

In a set of linear regressions, emphasis was a marginal predictor of certainty of God belief, $b=.24, S E$ of $b=.14,95 \% \mathrm{CI}$ of $b:-.03, .51, t(98)=1.77, p=.08$. When adding CREDs as a predictor to the model, however, only CREDs predicted belief certainty, $b=.55, S E$ of $b=$ $.18,95 \%$ CI of $b: .20, .91, t(97)=3.12, p<.01$; emphasis did not, $b=-.06, S E$ of $b=.16, t(97)$ $=-.39$, n.s. Together, these two sets of results replicate the pattern of findings in Study 1.

To test the hypothesis that CREDs predicts current religious status (following a religion or not) beyond the effect of religious emphasis, we conducted two logistic regressions. First, religious emphasis predicted current religious status, $b=.43, S E$ of $b=.14$, Wald $\chi^{2}(1)=9.95, p$ $<.01, O R=1.54,95 \%$ CI of OR: $1.18,2.00$. When including CREDs in the model, however, it was the superior predictor of current religious status, $b=.51, S E$ of $b=.18$, Wald $\chi^{2}(1)=7.75, p$ $<.01, O R=1.67,95 \%$ CI of OR: 1.16, 2.39, compared to emphasis, $b=.17$, SE of $b=.16$, Wald $\chi^{2}(1)=1.12, p=.29$. The predicted probability for persons with low CREDs exposure (-1SD) to report being currently affiliated with a religion was $33 \%$. In contrast, the predicted probability for persons with high CREDs exposure (+1SD) to report being currently affiliated with a religion was $78 \%$.

To test the hypothesis that CREDs exposure predicts current continuous levels of religiosity beyond the effect of religious emphasis, we conducted two regressions. In the first, emphasis (as the single predictor variable) predicted religiosity, $b=.30, S E$ of $b=.07,95 \% \mathrm{CI}$ of $b: .16, .43, t(98)=4.32, p<.001$. When adding CREDs as a predictor to the model, consistent with our hypothesis, CREDs predicted religiosity, $b=.27, S E$ of $b=.09,95 \%$ CI of $b: .09, .45, t$ 
$(97)=2.92, p<.01$, whereas emphasis was only a marginally significant predictor, $b=.15, S E$ of $b=.08, t(97)=1.83, p=.07$.

Finally, to test the alternative hypothesis that the effects of CREDs on current God belief, certainty of God belief, current religious status (dichotomous), and religiosity can be explained by one's own level of engagement in religious practice during upbringing, we re-ran the multiple regressions involving these outcomes, this time including the past religious practice item as an additional predictor in the first block. On its own, past religious practice predicted all outcomes, b's $>.26, p$ 's $<.05$. However, with CREDs added to each model, CREDs was a significant predictor, $b$ 's $>.28, p$ 's $<.04$, whereas one's own previous religious practice was not, $b$ 's $<.16$, $p$ 's $>.44$. These analyses do not support the alternative hypothesis.

\section{Discussion}

The results of Study 2 supported all four of our hypotheses. As in Study 1, CREDs exposure demonstrated both internal and discriminant validity (Hypothesis 1) and predicted both dichotomous and continuous measures of theistic belief (Hypothesis 2) while controlling for a measure of overall religious socialization. In support of Hypothesis 3, CREDs exposure predicted whether or not one followed a religion as well as one's level of religiosity. In support of Hypothesis 4, CREDs exposure remained a significant predictor of theism/non-theism and religiosity controlling not only for religious emphasis but also one's own previous religious practice.

\section{General Discussion}

The above studies empirically support the theorized significance of exposure to credibility enhancing displays for the acquisition of supernatural agent beliefs. Specifically, in 
both studies we found evidence that individuals who were exposed to high levels of religious CREDs by their caregivers were especially likely to report currently believing in the existence of God with high certainty. Conversely, those exposed to especially low levels of religious CREDs were most likely to currently report a lack of belief in God with high certainty. Importantly, these associations were strong when controlling for the related but distinct measure of religious emphasis (Hunsberger \& Altemeyer, 2006), suggesting that verbal expressions of religious belief and prodding of one's children to believe have limited efficacy in the absence of CREDs ${ }^{\text {iv }}$. In fact, CREDs exposure accounted for nearly all of the variance in belief and religiosity explained by the religious emphasis measure, suggesting that the majority of the causal power of 'religious socialization' lies in CREDs and that researchers interested in examining religious socialization focus particularly on CREDs exposure over more general constructs such as religious emphasis.

Our second study found that individuals who were exposed to high levels of religious CREDs were more likely to follow a religion and to have higher religiosity, suggesting that religious CREDs enhance not only the credibility of theism in general, but also the religious identities in which theistic beliefs are embedded. And further, across a series of regression analyses, we found no evidence for the alternative hypothesis that the effects of CREDs are reducible to one's own previous level of religious practice.

\section{Future Directions}

While our results are suggestive, there is a need for more research before this account is accepted. First, there is a need for experimental and prospective research, as the above studies utilize surveys and retrospective self-reports, which make it more difficult to infer causality. Experimental research will also allow us to better determine whether our results emerge from a 
domain specific CREDs effect (i.e., theistic CREDs increase the believability of theism but not the modeler's stated musical tastes) or from a domain general process by which observers more readily accept the representations offered by generally high-integrity models, models to whom they are more securely attached (Schnitker, Porter, Emmons, \& Barrett, 2012), or models who are intrinsically religious (Allport \& Ross, 1967). Experimental research would also help rule out the possibility that the current religious affiliations of participants, such as Christianity and Judaism (both of which emphasize honoring one's parents) strongly influence the retrospective reports of parents' religious actions and are responsible for the observed effect.

Further, since religious traditions vary substantially in terms of the specific behaviors they encourage, our measure included some items with broad language that may appear less strong as face valid representations of CREDs (e.g., item 6's focus on living a religiously pure life). Face validity is but one of many aspects of establishing construct validity, however, and our initial studies showed that our measure fared well overall (e.g., discriminant and predictive validity). In establishing the relevance of CREDs generally, we hope to encourage examination of particular religious communities and the development of more tradition-specific measures. In addition, our CREDs scale asked participants to complete the items based on their "overall impression" of their caregiver's actions, with the intent of obtaining an average of the actions of different individuals. Future research should explore the effects of CREDs performed by individual caregivers, which would allow for the evaluation of hypotheses about the relative importance of mothers and fathers (Baker-Sperry, 2001; Francis \& Brown, 1990; 1991; Francis \& Gibson, 1993) and of consistency between caregivers (Bader \& Desmond, 2006; Hoge, Petrillo, \& Smith; 1982; Myers, 1996) in comparison to CREDs exposure. 
Moreover, our studies focused on theism and non-theism in the United States. It is possible that CREDs exposure becomes more or less important as a determinant of supernatural belief acquisition depending on the socio-cultural context (Henrich, Heine, and Norenzayan, 2010) and the nature of the conceived supernatural agent. Willard and Norenzayan (2013), for instance, found no relationship between the percentage of religious adherents in an individual's community and their levels of paranormal belief. It is possible that supernatural agent beliefs in established religious traditions, which come in packages with a variety of other beliefs and norms, require more CREDs than supernatural agent beliefs with minimal 'cultural baggage,' such as vague beliefs in the existence of ghosts.

And finally, given the frequency with which apostates attribute their transition from theism to non-theism to religious hypocrisy (Lanman 2012; Bengston, Putney, \& Harris, 2013), it is quite possible that displays by a model directly contradicting verbally stated commitments (or what we call credibility undermining displays or "CRUDs") have a particularly powerful negative impact on religious socialization. Future research should examine the impact of particular CRUDs (e.g. drinking after verbally committing to its divine prohibition, etc.) on apostasy and the absence of supernatural agent beliefs.

In summary, while more research is required, initial evidence suggests that not all religious socialization is created equal. Rather, a CREDs bias may well be working to make religious actions more powerful than words in persuading cultural learners to acquire supernatural agent beliefs. Consequently, CREDs exposure may constitute an important predictor of who acquires supernatural agent beliefs and who does not, and may be placed 
alongside other relevant cognitive and cultural learning mechanisms in the development of a more comprehensive explanation of variation in supernatural agent beliefs.

\section{References}

Albrecht, S. L., Cornwall, M., \& Cunningham, P. H. (1988). Religious leave-taking:

Disengagement and disaffiliation among Mormons. In D. Bromley (Ed), Falling from the faith: The causes and consequences of religious apostasy. (pp. 62-80). London: Sage.

Allport, G. W., \& Ross, J. M. (1967). Personal religious orientation and prejudice. Journal of Personality and Social Psychology, 5(4), 432-443.

Atran, S. (2002). In gods we trust: The evolutionary landscape of religion. Oxford: Oxford University Press.

Bader, C. D., \& Desmond, S. A. (2006). Do as I say and as I do: The effects of consistent parental beliefs and behaviors upon religious transmission. Sociology of Religion, 67(3), 313-329.

Baker-Sperry, L. (2001). Passing on the faith: The father's role in religious transmission. Sociological Focus, 34(2), 185-198.

Baker, J. O. B., \& Smith, B. (2009). None too simple: Examining issues of religious nonbelief and nonbelonging in the United States. Journal for the Scientific Study of Religion, 48(4), 719-733.

Bandura, A. (1971). Social learning theory. New York: General Learning Press.

Bandura, A. (1986). Social foundations of thought and action. Englewood Cliffs: Pearson.

Barrett, J. (2004). Why would anyone believe in god? Walnut Creek: Alta Mira Press. 
Beit-Hallahmi, B. (2007). Atheists: A psychological profile. In M. Martin (Ed.), The Cambridge companion to atheism. (pp. 300-317). Cambridge: Cambridge University Press.

Beit-Hallahmi, B. (2015). Psychological perspectives on religion and religiosity. Hove: Routledge.

Bengtson, V. L., Putney, N.M., \& Harris, S. (2013). Families and faith: How religion is passed down across generations. Oxford: Oxford University Press.

Bering, J. M. (2006). The folk psychology of souls. Behavioral and Brain Sciences, 29(05), 453462.

Bering, J. (2010). The God instinct: The psychology of souls, destiny and the meaning of life. London: Nicholas Brealey Pub.

Bloom, P. (2004). Descartes' baby: How the science of child development explains what makes us human. Cambridge, MA: Basic Books.

Boyer, P. (2001). Religion explained: The evolutionary origins of religious thought. New York: Basic Books.

Buhrmester, M., Kwang, T., \& Gosling, S. D. (2011). Amazon's Mechanical Turk: A new source of inexpensive, yet high-quality, data? Perspectives on Psychological Science, 6, 3-5. doi: $10.1177 / 1745691610393980$

Cornwall, M. (1989). The determinants of religious behavior: A theoretical model and empirical test. Social Forces, 68, 572-592.

Dudley, R. L. (1978). Alienation from religion in adolescents from fundamentalist religious homes. Journal for the Scientific Study of Religion, 17(4), 389-398. 
Dudley, R. L. (1999). Youth religious commitment over time: A longitudinal study of retention. Review of Religious Research, 41 (1), 110-121.

Eagly, A. H., Wood, W., \& Chaiken, S. (1978). Causal inferences about communicators and their effect on opinion change. Journal of Personality and Social Psychology, 36(4), 424-435.

Festinger, L. (1957). A theory of cognitive dissonance. Stanford, CA: Stanford University Press.

Fisher, J. D., Fisher, W. A., Bryan, A. D., \& Misovich, S. J. (2002). Information-motivationbehavioral skills model-based HIV risk behavior change intervention for inner-city high school youth. Health Psychology, 21(2), 177-186.

Flor, D. L., \& Knapp, N. F. (2001). Transmission and transaction: predicting adolescents' internalization of parental religious values. Journal of Family Psychology, 15(4), 627645.

Francis, L. J., \& Brown, L. B. (1990). The predisposition to pray: A study of the social influence on the predisposition to pray among eleven-year-old children in England. Journal of Empirical Theology, 3, 23-34.

Francis, L. J., \& Brown, L. B. (1991). The influence of home, church and school on prayer among sixteen-year-old adolescents in England. Review of Religious Research, 33, 112 122.

Francis, L. J., \& Gibson, H. M. (1993). Parental influence and adolescent religiosity: A study of church attendance and attitude toward Christianity among adolescents 11 to 12 and 15 to 16 years old. International Journal for the Psychology of Religion, 3, 241-253.

Geertz, A. W., \& Markússon, G. I. (2010). Religion is natural, atheism is not: On why everybody is both right and wrong. Religion, 40(3), 152-165. 
Gervais, W.M., \& Najle, M. (in press). Learned faith: The influences of evolved cultural learning mechanisms on belief in gods. Psychology of Religion and Spirituality.

Gervais, W. M., \& Norenzayan, A. (2012). Analytic thinking promotes religious disbelief. Science, 336(6080), 493-496.

Gervais, W. M., Willard, A. K., Norenzayan, A., \& Henrich, J. (2011). The cultural transmission of faith: Why innate intuitions are necessary, but insufficient, to explain religious belief. Religion, 41(3), 389-410.

Harper, L. V., \& Sanders, K. M. (1975). The effect of adults' eating on young children's acceptance of unfamiliar foods. Journal of Experimental Child Psychology, 20(2), 206214.

Harris, P. L., \& Koenig, M. A. (2006). Trust in testimony: How children learn about science and religion. Child Development, 77(3), 505-524.

Harris, P. L., Pasquini, E. S., Duke, S., Asscher, J. J., \& Pons, F. (2006). Germs and angels: The role of testimony in young children's ontology. Developmental Science, 9(1), 76-96.

Henrich, J. (2009). The evolution of costly displays, cooperation, and religion: Credibility enhancing displays and their implications for cultural evolution. Evolution and Human Behaviour, 30, 244-260.

Henrich, J., Heine, S. J., \& Norenzayan, A. (2010). The weirdest people in the world? Behavioral and Brain Sciences, 33(2-3), 61-83.

Hoge, D. R., Petrillo, G. H., \& Smith, E. I. (1982). Transmission of religious and social values from parents to teenage children. Journal of Marriage and the Family, 44, 569-580. 
Hood Jr, R. W., Hill, P. C., \& Spilka, B. (2009). Psychology of religion: An empirical approach. New York: Guilford Press.

Horton, J.J., Rand, D.G., \& Zeckhauser, R.J. (2011). The online laboratory: Conducting experiments in a real labor market. Experimental Economics, 4, 399-42.

Hovland, C. I., \& Weiss, W. (1951). The influence of source credibility on communication effectiveness. Public Opinion Quarterly, 15(4), 635-650.

Hunsberger, B. (1980). A reexamination of the antecedents of apostasy. Review of Religious Research, 21(2), 158-170.

Hunsberger, B. (1983). Apostasy: A social learning perspective. Review of Religious Research, 25(1), 21-38.

Hunsberger, B. \& and Altemeyer, B. (2006). Atheists: A groundbreaking study of America's nonbelievers. Amherst: Prometheus Books.

Hunsberger, B., \& Brown, L. B. (1984). Religious socialization, apostasy, and the impact of family background. Journal for the Scientific Study of Religion, 23(3), 239-251.

Irons, W. (2001). Religion as a hard-to-fake sign of commitment. Evolution and the capacity for commitment, 292-309.

Johnson, D. (2005). God's punishment and public goods. Human Nature, 16(4), 410-446.

Jolliffe, I.T. (2002). Principle components analysis. New York: Springer Verlag New York.

Kelemen, D. (2004). Are children "intuitive theists"? Reasoning about purpose and design in nature. Psychological Science, 15(5), 295-301.

Lanman, J. (2012). The importance of religious displays for belief acquisition and secularization. Journal of Contemporary Religion, 27, 49-65. 
Lanman, J. (2013). Atheism and cognitive science. In S. Bullivant \& M. Ruse (Eds.), The Oxford Handbook of Atheism, (pp.483-496). Oxford: Oxford University Press.

Mason, W., \& Suri, S. (2012). Conducting behavioral research on Amazon's Mechanical Turk. Behavior Research Methods, 44(1), 1-23.

Myers, S. M. (1996). An interactive model of religiosity inheritance: The importance of family context. American Sociological Review, 61, 858-866.

Norenzayan, A., \& Gervais, W. M. (2013). The origins of religious disbelief. Trends in Cognitive Sciences, 17(1), 20-25.

Norenzayan, A., Gervais, W. M., \& Trzesniewski, K. H. (2012). Mentalizing deficits constrain belief in a personal God. PloS one, 7(5), e36880.

Norris, P. \& Inglehart, R. (2004). Sacred and secular: Religion and politics worldwide. Cambridge: Cambridge University Press.

Ozorak, E. W. (1989). Social and cognitive influences on the development of religious beliefs and commitment in adolescence. Journal for the Scientific Study of Religion, 28(4), 448463.

Paolacci, G., Chandler, J., \& Ipeirotis, P. G. (2010). Running experiments on Amazon Mechanical Turk. Judgment and Decision Making, 5, 411-419.

Purzycki, B. G., \& Sosis, R. (2009). The religious system as adaptive: Cognitive flexibility, public displays, and acceptance. In The biological evolution of religious mind and behavior (pp. 243-256). Springer Berlin Heidelberg.

Pyysiäinen, I. (2009). Supernatural agents: Why we believe in souls, gods, and Buddhas. Oxford: Oxford University Press. 
Reader, I. (1991). Religion in contemporary Japan. University of Hawaii Press.

Reader, I., \& Tanabe, G. J. (1998). Practically religious: Worldly benefits and the common religion of Japan. University of Hawaii Press.

Schnitker, S. A., Porter, T. J., Emmons, R. A., \& Barrett, J. L. (2012). Attachment predicts adolescent conversions at young life religious summer camps. International Journal for the Psychology of Religion, 22(3), 198-215.

Shariff, A.F., Cohen, A.B., \& Norenzayan, A. (2008). The devil's advocate: Secular arguments diminish both implicit and explicit religious belief. Journal of Cognition and Culture, 8 , 417-423.

Sherkat, D. E. (1991). Leaving the faith: Testing theories of religious switching using survival models. Social Science Research, 20(2), 171-187.

Sherkat, D. E., \& Wilson, J. (1995). Preferences, constraints, and choices in religious markets: An examination of religious switching and apostasy. Social Forces, 73(3), 993-1026.

Smith, G., Cooperman, A., Mohamed, B., Martinez, J., Alper, B., Sciupac, E., ...\& Ochoa, J. (2015). “America’s Changing Religious Landscape.” Washington, DC. Pew Research Center.

Sosis, R., \& Bulbulia, J. (2011). The behavioral ecology of religion: The benefits and costs of one evolutionary approach. Religion, 41(3), 341-362.

Sosis, R., \& Kiper, J. (2014). Religion is more than belief: What evolutionary theories of religion tell us about religious commitment. Challenges to Religion and Morality: Disagreements and Evolution, (Eds.) M. Bergmann and P. Kain, pp. 256-276. New York: Oxford University Press. 
Walster, E., Aronson, E., \& Abrahams, D. (1966). On increasing the persuasiveness of a low prestige communicator. Journal of Experimental Social Psychology, 2(4), 325-342.

Wildman, W., \& Sosis, R. (2011). Stability of groups with costly beliefs and practices. Journal of Artificial Societies and Social Simulation, 14(3), 6.

Willard, A. K., \& Norenzayan, A. (2013). Cognitive biases explain religious belief, paranormal belief, and belief in life's purpose. Cognition, 129(2), 379-391.

Zuckerman, P. (2007). Atheism: Contemporary numbers and patterns. In M. Martin (Ed.), The Cambridge Companion to Atheism, (pp. 47-65).Cambridge: Cambridge University Press. 


\section{Endnotes}

\footnotetext{
${ }^{\mathrm{i}}$ Two hundred and seventeen participants responded to the survey, but one participant's survey responses included numerous missing cases. Consequently, we dropped this participant's data,
} leaving 216 participant responses in the dataset.

ii Our sample contained more non-religious individuals (46\%) than would be expected in a random sample of Americans. A 2015 Pew survey indicates that only $22.8 \%$ of Americans are unaffiliated (Smith et al, 2015). We suspect this difference may be attributable to two factors. The first is the age of participants in our samples (Study 1: mean age $=37.3$ years; $S D=13.7$; Study 2 : mean age $=36.1$ years; $S D=13.1$ ). The recent Pew survey indicates that Millennials (birth years 1981-1996) are especially likely to be unaffiliated (34\% for Older Millennials and $36 \%$ for Younger Millennials) (Smith et al, 2015). The second factor is likely the higher levels of education among users of Amazon's Mechanical Turk (Paolacci et al., 2010), as religious disaffiliation is associated with educational attainment in the United States (Beit-Hallahmi, 2007).

iii Our CREDs scale focuses on displays by caregivers, as a significant body of evidence in both the psychology and sociology of religion (e.g. Cornwall, 1989; Dudley, 1978; 1999; Hood, Hill, \& Spilka, 2009; Hunsberger, 1980; 1983; Ozorak, 1989) points to the primary importance of parents in religious socialization and the lesser importance of other social models. Further research, however, should investigate potential effects of CREDs and CRUDs performed by peers and religious paragons.

${ }^{\text {iv }}$ While verbal expressions of religious belief appear to have limited efficacy in the absence of CREDs, the efficacy of CREDs in the absence of verbal expressions of belief is an open 
question. For an action to count as a CRED, by definition, it has to be linked in the mind of an observer with a previous verbal statement. Consequently, if there have been no verbal statements of the existence of supernatural agent, then no action can count as a CRED for a belief in the existence of a supernatural agent. However, religious traditions in a variety of contexts, such as Buddhism and Shinto in Japan (Reader, 1991; Reader and Tanabe, 1998), involve practices (e.g. offerings to ancestors and kami) that would count as CREDs for beliefs in supernatural agents, yet do not emphasize as particularly important either beliefs (e.g. in the existence of the ancestors or the kami) or religious identifications (e.g. as either Buddhist or Shinto). The effects of CREDs on the beliefs, practices, and identities of cultural learners in such environments remain to be explored. 


\section{Appendix}

\section{CREDs Exposure Scale used in Studies 1 and 2.}

Instructions: The following questions ask about experiences during your upbringing that relate to religion. Specifically, the questions ask about your perceptions of your primary caregiver or caregivers (i.e., parents or guardians). Please answer each of the following according to your overall impression of your caregiver(s) on the following scale:

$\begin{array}{lllllll}1 & 2 & 3 & 4 & 5 & 6 & 7\end{array}$

To no extent

at all
To an extreme

extent

1. To what extent did your caregiver(s) attend religious services or meetings?

2. To what extent did your caregiver(s) engage in religious volunteer or charity work?

3. Overall, to what extent did your caregiver(s) act as good religious role models?

4. Overall, to what extend did your caregiver(s) make personal sacrifices to religion?

5. To what extent did your caregiver(s) act fairly to others because their religion taught them so?

6. To what extent did your caregiver(s) live a religiously pure life?

7. To what extent did your caregiver(s) avoid harming others because their religion taught them so? 
Table 1

Characteristics of CREDs Exposure and Religious Emphasis Scales

CREDs Emphasis

\begin{tabular}{cccc}
\hline Study 1 $(N=216)$ & $\alpha$ & .92 & .98 \\
& $M(S D)$ & $3.27(1.51)$ & $3.33(1.76)$ \\
& $r$ & $.56^{* *}$ & \\
\hline Study 2 $(N=100)$ & $\alpha$ & .93 & .98 \\
& $M(S D)$ & $3.61(1.55)$ & $3.31(1.70)$ \\
& $r$ & $.60^{* *}$ &
\end{tabular}

Note: $r=$ Pearson $r$ correlation between CREDs and Emphasis; $* * p<.001$. 
Table 2

CREDs Scale Inter-Item Correlations, Means, and SDs

\begin{tabular}{|c|c|c|c|c|c|c|c|}
\hline Item & 1) & 2) & 3) & 4) & 5) & 6) & 7) \\
\hline 1) & $3.69(1.8)$ & & & & & & \\
\hline 2) & .63 & $2.48(1.7)$ & & & & & \\
\hline 3) & .71 & .65 & $3.52(1.9)$ & & & & \\
\hline 4) & .62 & .66 & .60 & $2.53(1.6)$ & & & \\
\hline 5) & .54 & .52 & .64 & .49 & $3.83(1.6)$ & & \\
\hline 6) & .69 & .62 & .73 & .65 & .58 & $2.97(1.7)$ & \\
\hline 7) & .57 & .53 & .67 & .53 & .83 & .63 & $3.88(2.1)$ \\
\hline
\end{tabular}


Table 3

Summary of Exploratory Factor Analysis for CREDs and Religious Emphasis items

\begin{tabular}{|c|c|c|}
\hline \multirow[b]{2}{*}{ Item } & \multicolumn{2}{|c|}{ Factor Loadings } \\
\hline & $\begin{array}{l}\text { Religious } \\
\text { Emphasis }\end{array}$ & CREDs \\
\hline Tell you how wrong it was to sin against a loving God? & .93 & -.08 \\
\hline $\begin{array}{l}\text { Make it clear that about the worst thing you could do in life } \\
\text { would be to abandon your religion? }\end{array}$ & .89 & -.11 \\
\hline $\begin{array}{l}\text { Teach you that your religion's rules about morality were } \\
\text { absolutely right, not to be questioned? }\end{array}$ & .87 & -.11 \\
\hline $\begin{array}{l}\text { Impress upon you that the unrepentant sinners would burn in hell } \\
\text { for all eternity? }\end{array}$ & .86 & -.18 \\
\hline Stress that it was responsibility to fight Satan all your life? & .86 & -.07 \\
\hline $\begin{array}{l}\text { Teach you that your religion was the truest religion, closest to } \\
\text { God? }\end{array}$ & .85 & -.01 \\
\hline Discuss moral do's and don'ts in religious terms? & .84 & .04 \\
\hline $\begin{array}{l}\text { Teach you that the persons who tried to change the meaning of } \\
\text { scripture and religious laws were evil? }\end{array}$ & .83 & -.16 \\
\hline $\begin{array}{l}\text { Make a personal commitment to God as your only hope and } \\
\text { savior? }\end{array}$ & .81 & .09 \\
\hline $\begin{array}{l}\text { Emphasize that you should read scriptures or other religious } \\
\text { materials? }\end{array}$ & .80 & .10 \\
\hline $\begin{array}{l}\text { Get you to do many extra religious acts so that the family } \\
\text { religion filled your life. }\end{array}$ & .80 & .02 \\
\hline $\begin{array}{l}\text { Stress being a good representative of your faith, who acted the } \\
\text { way a devout member of your religion was expected to act? }\end{array}$ & .79 & .13 \\
\hline Tell you how wonderful it would be in heaven for all eternity? & .79 & .03 \\
\hline Make religion the center, the most important part of your life? & .76 & .19 \\
\hline $\begin{array}{l}\text { Emphasize attending religious services as acts of personal } \\
\text { devotion? }\end{array}$ & .74 & .16 \\
\hline Teach you to strictly obey the commandments of almighty God? & .74 & .17 \\
\hline $\begin{array}{l}\text { Teach you to obey the persons who acted as God's } \\
\text { representatives, such as priests, ministers, or rabbis? }\end{array}$ & .73 & .10 \\
\hline Make religion relevant to almost all aspects of your life? & .71 & .23 \\
\hline Review the teaching of the religion at home? & .63 & .23 \\
\hline Have you pray before bedtime? & .62 & .19 \\
\hline $\begin{array}{l}\text { Overall, to what extent did your caregiver(s) act as good } \\
\text { religious role models? }\end{array}$ & -.01 & .86 \\
\hline $\begin{array}{l}\text { To what extent did your caregiver }(s) \text { avoid harming others } \\
\text { because their religion taught them so? }\end{array}$ & -.04 & .80 \\
\hline $\begin{array}{l}\text { To what extent did your caregiver(s) act fairly to others because } \\
\text { their religion taught them so? }\end{array}$ & -.07 & .79 \\
\hline
\end{tabular}


To what extent did your caregiver(s) live a religiously pure life?

To what extent did your caregiver(s) engage in religious

volunteer or charity work?

To what extent did your caregiver(s) attend religious services or

\section{meetings?}

Overall, to what extend did your caregiver(s) make personal

sacrifices to religion?

Eigenvalues

15.67

3.07

$\%$ of variance

Note: $N=216$. Correlation between factors $=.51$. Factor loadings above .30 appear in bold. Items in italics are from our new CREDs scale. 
Table 4

Effect of CREDs exposure on Theism and Religiosity

Dependent Variable Predictor: CREDs b's, \& p's

Study $1(N=216) \quad$ Study $2(N=100)$

1. Belief in God $b=.52, p<.001$ $b=.72, p<.001$

2. Certainty of Belief in God $b=.39, p<.01$ $b=.55, p<.01$

3. Follow a Religion $b=.43, p<.01$

4. Religiosity $b=.27, p<.01$

Note: Regression results presented above control for effects of religious emphasis (Hunsberger \& Altemeyer, 2006). $b=$ unstandardized regression coefficient. 